\title{
Alkaloid and benzopyran compounds of Melicope latifolia fruit exhibit anti-hepatitis $C$ virus activities
}

\author{
Aty Widyawaruyanti ${ }^{1,2}$, Mulyadi Tanjung ${ }^{2,3}$, Adita Ayu Permanasari ${ }^{2}$, Ratih Saputri, ${ }^{2,3}$, Lidya Tumewu², \\ Myrna Adianti ${ }^{2}$, Chie Aoki-Utsubo ${ }^{4}$, Hak Hotta $^{5}$, Achmad Fuad Hafid ${ }^{1,2}$ and Tutik Sri Wahyuni ${ }^{1,2^{*}}$ (D)
}

\begin{abstract}
Background: New agents for developing alternative or complementary medicine to treat the hepatitis $C$ virus $(\mathrm{HCV})$ are still needed due to high rates of HCV infection globally and the current limitations of available treatments. Treatment of HCV with a combination of direct acting antivirals have been shown to be approximately $90 \%$ effective but will be limited in the future due to the emergence of drug resistance and high cost. The leaves of Melicope latifolia have previously been reported to have anti-HCV activity and are a potential source of bioactive compounds for future novel drug development. This study aimed to evaluate the efficacy of the extract of $M$. latifolia fruit to treat HCV and to isolate its active compounds.
\end{abstract}

Method: M. latifolia fruit was extracted using methanol and purified using vacuum liquid chromatography (VLC) and Radial Chromatography. The anti-HCV activity was analyzed using cell culture lines Huh7it-1 and JFH1 (genotype 2a). Time-of-addition and immunoblotting studies were performed to identify the mode of action of the isolated active compounds. The structures of the active compounds were determined using nuclear magnetic resonance (NMR) spectra, UV, IR, and Mass Spectra.

Results: Six known compounds were isolated from M. latifolia fruit: O-methyloktadrenolon, alloevodionol, isopimpinellin, alloxanthoxyletin, methylevodionol, and $\mathrm{N}$-methylflindersine. $\mathrm{N}$-methylflidersine was the most active compound with $\mathrm{IC}_{50}$ value of $3.8 \mathrm{\mu g} / \mathrm{ml}$ while methylevodionol, isopimpinellin, and alloevodionol were less active. O-methyloktadrenolon and alloxanthoxyletin were moderately active with $\mathrm{IC}_{50}$ values of 10.9 and $21.72 \mu \mathrm{g} / \mathrm{ml}$, respectively. N-methylflidersine decreased level of HCV NS3 protein expression in the cells.

Conclusion: The alkaloid compound, N-methylflindersine which was isolated from M. latifolia possesses anti-HCV activity through post-entry inhibition and suppressed NS3 protein expression.

Keywords: Melicope latifolia, Hepatitis C virus, Alkaloids, Benzopyrans

\footnotetext{
* Correspondence: tutik-s-w@ff.unair.ac.id; wahyuni.tutiksri@yahoo.com

'Department of Pharmacognosy and Phytochemistry, Faculty of Pharmacy, Universitas Airlangga, Jl. Mulyorejo, Surabaya 60115, Indonesia

${ }^{2}$ Institute of Tropical Disease, Universitas Airlangga, Jl. Mulyorejo, Surabaya 60115, Indonesia

Full list of author information is available at the end of the article
}

(c) The Author(s). 2021 Open Access This article is licensed under a Creative Commons Attribution 4.0 International License, which permits use, sharing, adaptation, distribution and reproduction in any medium or format, as long as you give appropriate credit to the original author(s) and the source, provide a link to the Creative Commons licence, and indicate if changes were made. The images or other third party material in this article are included in the article's Creative Commons licence, unless indicated otherwise in a credit line to the material. If material is not included in the article's Creative Commons licence and your intended use is not permitted by statutory regulation or exceeds the permitted use, you will need to obtain permission directly from the copyright holder. To view a copy of this licence, visit http://creativecommons.org/licenses/by/4.0/. The Creative Commons Public Domain Dedication waiver (http://creativecommons.org/publicdomain/zero/1.0/) applies to the data made available in this article, unless otherwise stated in a credit line to the data. 


\section{Background}

The hepatitis $\mathrm{C}$ virus (HCV) is a pathogen that causes liver inflammation that can develop into cirrhosis and or hepatocellular carcinoma. No vaccine is presently available against $\mathrm{HCV}$ due to their extreme genetic variability and lack of animal models for vaccine testing [1, 2]. Seven genotypes of $\mathrm{HCV}$ are known to exist and are transmitted by sexual contact, sharing of injection equipment, reuse or inadequate sterilization of medical equipment and non-screened blood transfusion [2].

The current treatment of HCV uses direct acting antivirals (DAAs) which increased sustained virologic response $($ SVR) $>90 \%$ of people in clinical trials. DAAs treatment is divided into four classes: protease inhibitors, non-nucleoside polymerase inhibitors, nucleoside/ tide polymerase inhibitor, and NS5A inhibitors [3-5]. However, drug resistance and the affordability of treatment access in low income countries prevent their widespread use $[5,6]$. Potentially, new antiviral drugs may be able to be developed from plants with low side effects as there have been numerous reports on the antiviral activity of various phytochemicals against HCV [7-9].

Medicinal plants contain diverse chemical compounds that possess many potential bioactivities including anti$\mathrm{HCV}$ properties. Isolated compounds from a diverse range of medicinal plants have been reported as having anti-HCV properties such as saikosaponin b2, $\alpha-$ mangostin, oleanolic acid, ursolic acid, EGCG, glycyrrhizin, chalepin, and pseudane IX [7-10]. Chalepin and pseudane IX, isolated from Ruta angustifolia, exhibited anti-HCV activity by reducing the virus particle production and decreasing HCV NS3 protein level [11]. Some active compounds from plants have been so successful that they have reached clinical trials such as naringenin and silymarin/silibinin [12].

M. latifolia belongs to Rutaceae family. The leaves of $M$. latifolia were used as traditional medicine for the treatment of fever, cramps, jaundice and malaria [13]. Several species of Melicope are reported to possess flavonoids, alkaloids, coumarins and other metabolites [14, 15]. These compounds possess potential bioactivities and have previously been shown to have anti-viral activity [14]. The alkaloid, pseudane IX and a benzopyran compound, chalepin, isolated from $R$. angustifolia have exhibited anti-HCV activities. The alkaloid compound, namely APS, isolated from Maytenus ilicifolia, also exhibited anti-HCV activity by inhibited HCV replication and significantly reduced HCV NS5A [8]. Two novel myrioneuron alkaloids, schoberine $\mathrm{B}$ and myriberine $\mathrm{B}$ were isolated from aerial part of Myrioneuron faberi [16]. These alkaloids compounds were evaluated against $\mathrm{HCV}$ and showed strong anti-HCV activity. Various compounds from many of genus Melicope have been isolated. The leaves of $M$. triphylla are reported to contain 5,8-dihydroxy-3,7dimethoxy-3,4-methylenedioxyflavone, 7-hydroxy-3,5-di-methoxy-3',4' -methylenedioxyflavone, 7-(2,3-dihydroxy-3-methylbutoxy)-3, 5-mimethoxy-3', 4'-methylene-dioxyflavone, 7-(2,3-dihydroxy-3-methylbutoxy)-3-3',4',5-tetramethoxyflavone, and 7-(2,3-dihydroxy-3-methylbutoxy)-3,3' 4',5,8-pentamethoxyflavone. The O-prenylated flavonoid (3,5,4'-trihydroxy-8,3'dimethoxy-7-(3-methylbut-2-enoxy) flavone was isolated from M. pteleifolia [14]. Two quinoline alkaloids, buchapine and 3-(3-methyl-2-butenyl)-4-[(3-methyl-2-butenyl)oxy]-2(1H)-quinolinone, and three furoquinoline alkaloids, roxiamines $\mathrm{A}, \mathrm{B}$, and $\mathrm{C}$ were isolated from flowers, leaves, and twigs of $M$. lunu-ankenda and the quinoline alkaloids revealed anti-HIV activity [17]. Our previous screening of 21 plants from Indonesia revealed that the ethanol extract of $M$. latifolia leaves exhibited anti-HCV activity with an $\mathrm{IC}_{50}$ of 3.5 and $2.1 \mu \mathrm{g} / \mathrm{ml}$ against HCV J6/JFH1-P47 and -P1 strains respectively. The cytotoxicity concentration $50 \%\left(\mathrm{CC}_{50}\right)$ was found to be $>100 \mu \mathrm{g} / \mathrm{ml}$. The mode of action of the tested extracts was through their action in the entry and postentry steps of HCV life cycle. Moreover, the HCV NS3 protein level has also been reported to be suppressed by the $M$. latifolia extract [10]. The fraction of the M. latifolia leaf extract which contained the alkaloid compound, N-methylflindersine, showed a strong inhibition against $\mathrm{HCV}$ [15]. These results may provide a potential to find anti-HCV compounds from other parts of Melicope latifolia, Therefore, this current study was conducted to determine the anti-HCV activity of the $M$. latifolia fruit. We then further fractioned, purified and isolated of its active constituents to obtain anti-HCV compounds.

\section{Methods}

\section{Cells and viruses}

Hepatocyte cells of Huh7it-1 [18] were cultivated in DMEM-Dulbeco's Modiffied Eagle Medium (GIBCO Invitrogen). The medium was supplemented with $10 \%$ Fetal Bovine Serum (FBS, GIBCO-Invitrogen), $0.15 \mathrm{mg} /$ ml kanamycin solution (SIGMA) and 1x Non-Essential Amino Acids (NEAA, GIBCO-Invitrogen). The cell culture was incubated in $5 \% \mathrm{CO}_{2}$ at $37^{\circ} \mathrm{C}$. HCV JFH1a was propagated in Huh7it-1 suspended in $4 \mathrm{ml} \mathrm{JFH1} \mathrm{suspen-}$ sion and $4 \mathrm{ml}$ DMEM and was incubated at $37^{\circ} \mathrm{C}$ in $5 \%$ $\mathrm{CO}_{2}$ for $4 \mathrm{~h}$. The suspension was divided into eight flasks and the supernatant was harvested on the third day. The supernatant was concentrated and examined for its viral titration and stored at $-80^{\circ} \mathrm{C}[10]$.

\section{Extraction and isolation of benzopyran compounds of Melicope latifolia fruit}

M. latifolia were collected at Cangar forest, East Java, Indonesia. The collected plants were verified by botanist 
researchers at Purwadadi Botanical Garden-Indonesia Institute of Science, Purwadadi, East Java, Indonesia (Number of determination: 0340/IPH.06/H/III/2017). The voucher specimen has been deposited in Institute of Tropical Disease, Universitas Airlangga. The fruits of plant were dried at room temperature and pulverized. Dried and powdered fruits of M. latifolia ( $450 \mathrm{~g}$ ) were extracted using methanol as a solvent and yielded $25.5 \mathrm{~g}$ of dried methanol extract. The extract was further partitioned using $\mathrm{n}$-hexane. The dried $\mathrm{n}$-hexane extract (14.0 g) was then subjected to vacuum liquid chromatography (VLC) using silica gel as the stationary phase and nhexane:ethyl acetate in a gradient composition $(9: 1 ; 8.5$ : $1.5 ; 8: 2 ; 1: 1$ ) as the mobile phase. Five fractions (Fraction A-E) were obtained. Among the fractions, fraction B was observed as intense violet spots under UV light which indicated the presence of coumarin compounds [19]. Further separation of Fraction B (7 g) was conducted by VLC using n-hexane:ethyl acetate in a gradient composition (9.5:0.5 until 8:2) as the mobile phase and yielded six sub-fractions (B1-B6). Separation of B3 (3 g) by radial chromatography using $\mathrm{n}$-hexane:diisoprophyl ether in a gradient composition (9.5:0.5 until 8:2) yielded three further sub-fractions (B31, B32 and B33). Purification of B31 ( $49.5 \mathrm{mg}$ ) by radial chromatography using $\mathrm{n}$-hexane: diisoprophyl ether in a gradient composition (9.75:0.25 until 8:2) yielded a benzopyran compound (O-methyloktadrenolon; $26.8 \mathrm{mg}$ ) in the form of a pale yellow oil. Purification of B32 $(107.9 \mathrm{mg})$ by same method, yielded a benzopyran compound (alloevodionol; $49.8 \mathrm{mg}$ ) in form of a pale yellow solids.

\section{Extraction and isolation of alkaloid compounds of Melicope latifolia fruit}

The dried fruit of M. latifolia (500 g) was extracted using methanol as a solvent and yielded $115 \mathrm{~g}$ of concentrated methanol extract. The extract was further partitioned using n-hexane with a solvent composition of 1:1. The methanol phase was then separated and treated with citric acid until $\mathrm{pH} 3-4$. Further partition of methanol phase was then conducted using ethyl acetate in which the ethyl acetate extract phase and alkaloid extract phase were obtained. The ethyl acetate extract phase was then dried to obtain the final ethyl acetate extract $(33 \mathrm{~g})$. Meanwhile, alkaloid extract phase was again partitioned using ethyl acetate and washed with distilled water until $\mathrm{pH} 7$ to obtain alkaloid extract $(5 \mathrm{~g})$.

Separation of the ethyl acetate extract $(33 \mathrm{~g})$ was done by VLC using $n$-hexane: ethyl acetate as the solvent with increased polarity (9:1 until 3:7). Three main fractions were obtained (Fraction A-C). Fraction B and C were observed as intense violet spots under UV light. Fraction B (975 mg) was subjected to VLC using n-hexane:ethyl acetate (9:1 until 6:4) and chloroform:ethyl acetate (7:3 until 1:1) to obtain three sub-fractions (B1-B3). The Thin Layer Chromatography (TLC) analysis of B3 showed intense violet spots under UV light which indicated the presence of a coumarin compound [19]. Purification of B3 $(105 \mathrm{mg})$ by radial chromatography using nhexane:acetone (9.5:0.5 until 8:2) yielded a coumarin compound (alloxanthoxyletin: $12.2 \mathrm{mg}$ ) in the form of a white solid.

Separation of fraction C $(625.0 \mathrm{mg})$ by VLC using nhexane:ethyl acetate $(0: 1$ until 7.5:2.5) yielded two subfractions, $\mathrm{C} 1$ and $\mathrm{C} 2$. Further purification of $\mathrm{C} 2(89.0$ $\mathrm{mg}$ ) by radial chromatography using $\mathrm{n}$-hexane:chloroform (9:1 until 7:3) yielded a coumarin compound (isopimpinellin; $8.4 \mathrm{mg}$ ) in the form of a pale yellow solid.

Separation of fraction A $(325 \mathrm{mg})$ by radial chromatography using $\mathrm{n}$-hexane:chloroform $(7: 3 ; 1: 1)$ and chloroform yielded three sub-fractions, A1-A3. Purification of A1 (141 mg) was done by radial chromatography using n-hexane:chloroform $(9: 1 ; 8: 2 ; 7: 3)$ to obtain benzopyran compound (methylevodionol; $41 \mathrm{mg}$ ) in the form of an oil.

The separation of the alkaloid extract was conducted by VLC to obtain three fractions (fraction A-C). The separation of Fraction A by radial chromatography using n-hexane:ethyl acetate $(9: 1 ; 8: 2)$ yielded three subfractions (A1-A3). Radial chromatography was applied to purify A3 using n-hexane:acetone $(9: 1 ; 7: 3)$ and obtained an alkaloid compound (N-methylflindersine; 12.3 $\mathrm{mg}$ ) in the form of a yellow oil.

\section{Antiviral activity assay}

The hepatocyte cells of Huh7it-1 were seeded on a 48 well plate with a cell density of $5.4 \times 10^{4}$ and incubated for $24 \mathrm{~h}$. Samples with concentrations of 100, 30, 10, 1, 0.1 and $0.01 \mu \mathrm{g} / \mathrm{ml}$ were mixed with HCV JFH1a with multiple infections (MOI 0.1) and then inoculated onto cells and incubated for $2 \mathrm{~h}$. The supernatant was removed and washed with medium and placed back into solutions containing the same concentrations of extract. The cultures were then incubated for $48 \mathrm{~h}$ and the supernatant was taken to examine the titer infection of the sample by immunostaining [10].

\section{Time-of-addition experiment}

A time addition experiment was performed to analyze the effect of the extract on the HCV life cycle. Entry inhibition was conducted by treated cells with extracts during viral inoculation to evaluate the inhibition in binding, entry and endocytosis. Post entry inhibition was conducted by treating cells with the extracts after viral inoculation. Supernatants were collected and viral titration and immunostaining was used to assess the mode of action [20]. 


\section{Viral titration and immunostaining}

Viral titration was performed by serially diluting the culture supernatant in DMEM medium and inoculating onto Huh7it-1 cells. After incubation for $41 \mathrm{~h}$, the cells were fixed by $3.7 \%$ formaldehyde and permeabilized with $0.5 \%$ triton X-100 for $10 \mathrm{~min}$. First antibody (HCV infected serum patient) was used in $1 \%$ bovine serum albumin (BSA) /2\%BlockIce/ phosphate buffer saline (PBS) with a 300x dilution then incubated for $60 \mathrm{~min}$. Second antibody (HRP-Goat anti human) was used in 1\%BSA/ $2 \%$ BlockIce/PBS with a $400 \mathrm{x}$ dilution $(50 \mu \mathrm{l} /$ well $)$ and then incubated for $60 \mathrm{~min}$ at room temperature. To visualize the infectious foci, 3,3'-diaminobenzidine (DAB) staining (DAB Thermo Scientific, USA) was used for 15 min until a brown color was observed. SPSS probit was used to calculate inhibition concentration 50\% $\left(\mathrm{IC}_{50}\right)$ values.

\section{Cytotoxicity assay}

The cytotoxicity analysis was assessed using MTT assay 3-(4,5-Dimethylthiazol-2-Yl)-2,5-Diphenyltetrazolium Bromide [20, 21]. Solutions with extract concentrations of $1000,400,100,50,10,1$ and $0.1 \mu$ l were added onto Huh7it-1 cells in 96 well plates. After $46 \mathrm{~h}$ incubation, the medium was removed and $150 \mu \mathrm{l} /$ well of $10 \% \mathrm{MTT}$ was added then incubated for $4 \mathrm{~h}$. The purple precipitates were then dissolved in dimethyl sulfoxide (DMSO). The purple solution was measured for UV absorbance using a microplate reader at $560 \mathrm{~nm}$. SPSS probit was used to calculate the cytotoxic concentration 50\% $\left(\mathrm{CC}_{50}\right)$.

\section{Immunoblotting}

Huh7it-1 cells were lysed with Ripa buffer and the amount of protein was checked using a bichincronic acid (BCA) assay kit. The proteins were separated in (sodium dodecyl sulfate polyacrylamide gel electrophoresis (SDS-PAGE) gel and transferred onto a PVDF membrane (Millipore, Bed-ford, MA, USA). Five percent skimmed milk was added to block nonspecific binding and incubated for $60 \mathrm{~min}$. First antibody, HCV NS3-specific mouse monoclonal antibody (clone H23; Abcam, Cambridge, MA, USA) and glyceraldehyde-3-phosphate dehydrogenase (GAPDH) antibody (MBL) was added and incubated for $1 \mathrm{~h}$. The $0.05 \%$ PBST was used for membrane washing. Second antibody, HRP-conjugated goat anti mouse immunoglobulin (MBL) was incubated for $1 \mathrm{~h}$ and the respective protein was visualized using Clarity Western ECL substrate (Biorad). The chemical luminescence was detected using ImageQuant LAS 4000 (GE healthcare) [20].

\section{Results \\ Identification of isolated compounds of Melicope latifolia fruit extract}

Six known compounds were isolated from the $M$. latifolia fruit extract. Structure elucidation of compounds was determined by Nuclear Magnetic Resonance (NMR) spectra, ultra violet (UV), infrared (IR) spectroscopy and mass spectra (MS) data. NMR spectra were measured on a JEOL JNM-ECA $400 \mathrm{MHz}$ FTNMR spectrophotometer in $\mathrm{CDCl}_{3}$ solvent. UV spectra were recorded in methanol on a Shimadzu series 1800 UV-VIS spectrophotometer. IR spectra were recorded in $\mathrm{KBr}$ on a One Perkin Elmer instrument. Mass spectra were measured on an ESI-TOF Waters LCT Premier XE producing pseudo-molecular ions, $[\mathrm{M}+\mathrm{H}]^{+}$positive ion mode. The molecular structures of isolated compounds are described in Fig. 1.

\section{O-methyloktadrenolon}

The compound showed a UV maximum absorption $(\mathrm{MeOH})$ at $\lambda_{\max } n m(\log \varepsilon): 217$ (2.95); 223 (2.80); 278 (3.12); 289 (3.05) and 355 (2.14). IR spectrum showed a band at $v_{\max }\left(\mathrm{cm}^{-1}\right): 3055 ; 2974 ; 2935 ; 1697 ; 1639-$ 1579; and 1184. The mass spectrum of the compound showed a quasi-molecular ion $[\mathrm{M}+\mathrm{H}]^{+}$at $m / z 315.1595$ corresponding to the molecular formula $\mathrm{C}_{19} \mathrm{H}_{23} \mathrm{O}_{4}$.

${ }^{1} \mathrm{H}-\mathrm{NMR}\left(\mathrm{CDCl}_{3}\right) \delta_{\mathrm{H}} \mathrm{ppm}: 5.51(1 \mathrm{H}, \mathrm{d}, J=9.8 \mathrm{~Hz}, \mathrm{H}-$ 3), $6.48(1 \mathrm{H}, \mathrm{d}, J=9.8 \mathrm{~Hz}, \mathrm{H}-4), 5.53(1 \mathrm{H}, \mathrm{d}, J=9.8 \mathrm{~Hz}$, H-9), 6.59 (1H, d $J=9.8 \mathrm{~Hz}, \mathrm{H}-10), 2.50$ (3H, s, H-12), 1.42 (3H, s, H-13/14), 1.41 (3H, s, H-15/16), 3.75 (3H, s, 5- $\left.\mathrm{OCH}_{3}\right) .{ }^{13} \mathrm{C}-\mathrm{NMR} \quad\left(\mathrm{CDCl}_{3}\right) \quad \delta_{\mathrm{C}}$ ppm: 201.1 (C-11), 153.7 (C-5), 151.5 (C-6a), 150.6 (C-10b), 127.9 (C-3), 127.8 (C-9), 116.8 (C-10), 116.2 (C-4), 117.7 (C-6), 108.2 (C-4a), 106.6 (C-10a), 77.2 (C-8), 76.9 (C-2), 32.7 (C-12), 28.0 (C-13/14), 27.9 (C-15/16), $63.7\left(5-\mathrm{OCH}_{3}\right)$. The NMR spectra data are consistent with published data [22].

\section{Alloevodionol}

The compound showed a UV maximum absorption (MeOH) at $\lambda_{\max } \mathrm{nm} 217$ (3.04) and 257 (3.24). IR spectrum showed a band at $v_{\max }\left(\mathrm{cm}^{-1}\right): 3051 ; 2970$; 2864; 1639; 1610-1587 and 1205. The molecular formula was determined to be $\mathrm{C}_{14} \mathrm{H}_{16} \mathrm{O}_{4}$.

${ }^{1} \mathrm{H}-\mathrm{NMR}\left(\mathrm{CDCl}_{3}\right) \delta_{\mathrm{H}} \mathrm{ppm}: 5.41(1 \mathrm{H}, \mathrm{d}, J=10.1 \mathrm{~Hz}, \mathrm{H}-$ 3), $6.55(1 \mathrm{H}, \mathrm{d}, J=10.1 \mathrm{~Hz}, \mathrm{H}-4), 6.00$ (1H, s, H-6), 2.66 (3H, s, H-12), $1.48(3 \mathrm{H}, \mathrm{s}, \mathrm{H}-13 / 14), 13.83(1 \mathrm{H}, \mathrm{s}, 7-$ $\mathrm{OH}), 3.83\left(3 \mathrm{H}, \mathrm{s}, 5-\mathrm{OCH}_{3}\right) .{ }^{13} \mathrm{C}-\mathrm{NMR}\left(\mathrm{CDCl}_{3}\right) \delta_{\mathrm{C}} \mathrm{ppm}$ : 203.4 (C-11), 166.4 (C-7), 161.0 (C-5), 156.3 (C-9), 124.7 (C-3), 116.6 (C-4),106.0 (C-8), 102.8 (C-10), 92.3 (C-6), 78.0 (C-2), 33.2 (C-12), 27.9 (C-13/14), $55.8\left(5-\mathrm{OCH}_{3}\right)$. The NMR spectra data are consistent with published data [22]. 
<smiles>COc1c2c(c3c(c1C(C)=O)OC(C)C=C3)C=CC(C)(C)O2</smiles>

(A)

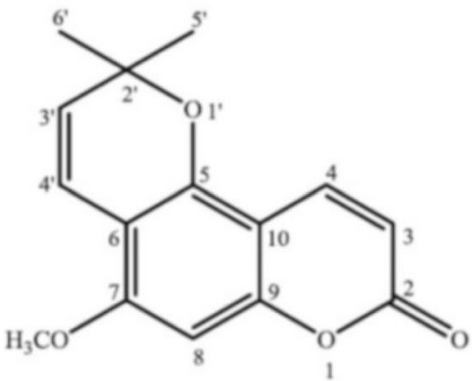

(D)<smiles>COc1cc(O)c(C=O)c2c1C=CC(C)(C)O2</smiles>

(B)<smiles>COc1c2ccoc2c(OC)c2oc(=O)ccc12</smiles>

(C)<smiles>COc1cc2c(c(OC)c1C(C)=O)C=CC(C)(C)O2</smiles>

(E)<smiles></smiles>

(F)

Fig. 1 Chemical structure of isolated compounds of Melicope latifolia fruit. a O-methyloktadrenolon; b Alloevodionol; c Isopimpinellin; d Alloxanthoxyletin; e Methylevodionol; and $\mathbf{f} \mathrm{N}$-methylflindersine

\section{Isopimpinellin}

The compound showed a UV maximum absorption $(\mathrm{MeOH})$ at $\lambda_{\max } \mathrm{nm}(\log \varepsilon): 223.10$ (4.20); 241.10 (4.00); 248.60 (4.00); 268.60 (4.09) and 311.30 (3.91). IR spectrum showed a band at $v_{\max }\left(\mathrm{cm}^{-1}\right)$ : $3128 ; 2952$; 2850, 1751, 1606-1491, and 1145. Mass spectra showed a quasi-molecular ion at $\mathrm{m} / z$ 247.0609. The molecular formula was therefore determined to be $\mathrm{C}_{13} \mathrm{H}_{11} \mathrm{O}_{5}$ (calculated $[\mathrm{M}+\mathrm{H}]^{+}$247.0606).

${ }^{1} \mathrm{H}-\mathrm{NMR}\left(\mathrm{CDCl}_{3}\right) \delta_{\mathrm{H}} \mathrm{ppm}: 8.12(1 \mathrm{H}, \mathrm{d}, J=9.8 \mathrm{~Hz}, \mathrm{H}-$ 4), $7.62\left(1 \mathrm{H}, \mathrm{d}, J=2.3 \mathrm{~Hz}, \mathrm{H}-2^{\prime}\right), 7.00(1 \mathrm{H}, \mathrm{d}, J=2.3 \mathrm{~Hz}$, H-3'), $6.29(1 \mathrm{H}, \mathrm{d}, J=9.8 \mathrm{~Hz}, \mathrm{H}-3), 4.16(3 \mathrm{H}, \mathrm{s}, 5-$ $\left.\mathrm{OCH}_{3}\right), 4.17\left(3 \mathrm{H}, \mathrm{s}, 8-\mathrm{OCH}_{3}\right) .{ }^{13} \mathrm{C}-\mathrm{NMR}\left(\mathrm{CDCl}_{3}\right) \delta_{\mathrm{C}}$ ppm: 160.6 (C-2), 150.0 (C-7), 145.2 (C-4), 144.4 (C-8), 143.8 (C-9), 139.5 (C-2'), 128.3 (C-5), 114.8 (C-6), 107.7 (C-10), 112.9 (C-3), $105.2\left(\mathrm{C}-3^{\prime}\right), 61.8\left(5-\mathrm{OCH}_{3}\right), 60.89$ $\left(8-\mathrm{OCH}_{3}\right)$. The NMR spectra data are consistent with published data [23].

\section{Alloxanthoxyletin}

The compound showed a UV maximum absorption $(\mathrm{MeOH})$ at $\lambda_{\max } \mathrm{nm}(\log \varepsilon): 224$ (4.14); 282 (4.11); and 324 (3.92). IR spectrum showed a band at $v_{\max }\left(\mathrm{cm}^{-1}\right)$ :
3056; 2977; 2925; 2850; 1735; 1610-1568; and 1122. The mass spectrum showed a quasi-molecular ion $[\mathrm{M}+\mathrm{H}]^{+}$ at $m / z 259.0979$. The molecular formula was determined to be $\mathrm{C}_{15} \mathrm{H}_{15} \mathrm{O}_{4}$ (calculated $[\mathrm{M}+\mathrm{H}]^{+}$259.0970).

${ }^{1} \mathrm{H}-\mathrm{NMR}\left(\mathrm{CDCl}_{3}\right) \delta_{\mathrm{H}} \mathrm{ppm}: 6.16(1 \mathrm{H}, \mathrm{d}, J=9.6 \mathrm{~Hz}, \mathrm{H}-$ 3), $6.61\left(1 \mathrm{H}, \mathrm{d}, J=9.9 \mathrm{~Hz}, \mathrm{H}-4^{\prime}\right), 7.96(1 \mathrm{H}, \mathrm{d}, J=9.6 \mathrm{~Hz}$, $\mathrm{H}-4), 5.5\left(1 \mathrm{H}, \mathrm{d}, J=9.9 \mathrm{~Hz}, \mathrm{H}-3^{\prime}\right), 6.35(1 \mathrm{H}, \mathrm{s}, \mathrm{H}-8), 3.87$ $\left(3 \mathrm{H}, \mathrm{s}, 7-\mathrm{OCH}_{3}\right) .{ }^{13} \mathrm{C}-\mathrm{NMR}\left(\mathrm{CDCl}_{3}\right) \delta_{\mathrm{C}} \mathrm{ppm}: 161.6(\mathrm{C}-$ 2), 158.3 (C-7), 155.9 (C-9), 150.3 (C-5), 138.7 (C-4), 111.2 (C-3), 106.6 (C-6), 127.6 (C-3'), 116,1 (C-4'), 103.8 (C-10), 91.6 (C-8), 77.8 (C-2'), 28.0 (C-5'/6'), 56.0 $\left(7-\mathrm{OCH}_{3}\right)$. The NMR spectra data are consistent with published data [24].

\section{Methylevodionol}

The compound showed a UV maximum absorption $(\mathrm{MeOH})$ at $\lambda_{\max } \mathrm{nm}(\log \varepsilon): 312$ (3.59); 287 (3.76); 257 (4.12) and 229 (4.23). IR spectrum showed a band at $v_{\max }\left(\mathrm{cm}^{-1}\right): 2974 ; 2925 ; 2850 ; 1622 ; 1598-1439$ and 1126. The mass spectrum showed a quasi-molecular ion $[\mathrm{M}+\mathrm{H}]^{+}$at $m / z$ 263.1288. The molecular formula was determined to be $\mathrm{C}_{15} \mathrm{H}_{19} \mathrm{O}_{4}$ (calculated $[\mathrm{M}+\mathrm{H}]^{+}$ 263.1283). 
${ }^{1} \mathrm{H}-\mathrm{NMR}\left(\mathrm{CDCl}_{3}\right) \delta_{\mathrm{H}}$ ppm: $5.51(1 \mathrm{H}, \mathrm{d}, J=10.0 \mathrm{~Hz}, \mathrm{H}-$ 3), $6.46(1 \mathrm{H}, \mathrm{d}, J=10.0 \mathrm{~Hz}, \mathrm{H}-4), 6.18(1 \mathrm{H}, \mathrm{s}, \mathrm{H}-9), 2.48$ $(3 \mathrm{H}, \mathrm{s}, \mathrm{H}-12), 1.41(3 \mathrm{H}, \mathrm{s}, \mathrm{H}-13 / 14), 3.74(3 \mathrm{H}, \mathrm{s}, 6-$ $\left.\mathrm{OCH}_{3}\right), 3.76\left(3 \mathrm{H}, \mathrm{s}, 8-\mathrm{OCH}_{3}\right) .{ }^{13} \mathrm{C}-\mathrm{NMR}\left(\mathrm{CDCl}_{3}\right) \delta_{\mathrm{C}}$ ppm: 201.9 (C-11), 157.6 (C-8), 156.0 (C-10), 154.2 (C6), 127.8 (C-3), 118.3 (C-7), 116.5 (C-4), 108.0 (C-5), 96.1 (C-9), 76.9 (C-2), 32.6 (C-12), 27.9 (C-13/14), 55.8 $\left(6-\mathrm{OCH}_{3}\right), 55.8\left(6-\mathrm{OCH}_{3}\right)$. The NMR spectra data are consistent with published data [22].

\section{$\mathrm{N}$-methylflindersine}

The compound showed a UV maximum absorption $(\mathrm{MeOH})$ at $\lambda_{\max } \mathrm{nm}(\log \varepsilon): 226$ (4.29); 285 (3.20), 333 (3.65), 348 (3.69) and 365 (3.52) nm typical for a quinolinone skeleton [25]. IR spectrum showed a band at $v_{\max }$ $\left(\mathrm{cm}^{-1}\right)$ : 3083; 3055; 2974; 2896; 2879; 1730; 1612; 1452; 1236; and 1203. The mass spectrum showed a quasimolecular ion $[\mathrm{M}+\mathrm{H}]^{+}$at $m / z$ 242.1180. The molecular formula was determined to be $\mathrm{C}_{15} \mathrm{H}_{16} \mathrm{NO}_{2}$ (calculated $[\mathrm{M}+\mathrm{H}]^{+}$242.1181).

${ }^{1} \mathrm{H}-\mathrm{NMR}\left(\mathrm{CDCl}_{3}\right) \delta_{\mathrm{H}} \mathrm{ppm}: 5.52(1 \mathrm{H}, \mathrm{d}, J=10.0 \mathrm{~Hz}, \mathrm{H}-$ 3), $6.74(1 \mathrm{H}, \mathrm{d}, J=10.0 \mathrm{~Hz}, \mathrm{H}-4), 7.30(1 \mathrm{H}, \mathrm{d}, \mathrm{H}-7), 7.53$ $(1 \mathrm{H}, \mathrm{m}, \mathrm{H}-8), 7.95(1 \mathrm{H}, \mathrm{dd}, J=7.8 ; 1.5 \mathrm{~Hz}, \mathrm{H}-10), 7.21$ $(1 \mathrm{H}, \mathrm{t}, J=7.8 \mathrm{~Hz}, \mathrm{H}-9), 1.50(3 \mathrm{H}, \mathrm{s}, \mathrm{H}-11 / 12), 3.68(3 \mathrm{H}$, $\left.\mathrm{s}, \mathrm{N}-\mathrm{CH}_{3}\right) .{ }^{13} \mathrm{C}-\mathrm{NMR}\left(\mathrm{CDCl}_{3}\right) \delta_{\mathrm{C}} \mathrm{ppm}: 161.0(\mathrm{C}-5)$, 155.2 (C-10b), 130.9 (C-8), 139.3 (C-6a), 126.4 (C-3), 123.1 (C-10), 121.7 (C-9), 117.9 (C-4), 116.1 (C-10a),

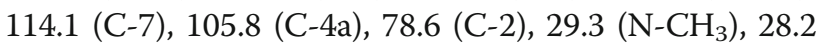
(C-11/12). The NMR spectra data are consistent with published data [26].

Anti HCV activity and cytotoxicity of isolated compounds The isolated compounds were evaluated against $\mathrm{HCV}$ in cultured Huh7it-1 cells in a dose dependent manner. The cytotoxicity was determined by MTT analysis. N-methylflindersine and O-methyloktadrenolon had stronger activities than the other testedcompounds. N-methylflindersine exhibited the strongest effect with an $\mathrm{IC}_{50}$ value of $3.8 \pm 2.7 \mu \mathrm{g} / \mathrm{ml}$, followed by moderate $\mathrm{HCV}$ inhibition activity of $\mathrm{O}$ methyloktadrenolon and alloxanthoxyletin with $\mathrm{IC}_{50}$ values of $10.9 \pm 1.2 \mu \mathrm{g} / \mathrm{ml}$ and $21.72 \mu \mathrm{g} / \mathrm{ml}$,

Table 1 The anti-HCV activity $\left(\mathrm{IC}_{50}\right)$ and cytotoxicity $\left(\mathrm{CC}_{50}\right)$ of compounds isolated from M. latifolia fruit extract

\begin{tabular}{llll}
\hline Sample & $\mathbf{I C}_{\mathbf{5 0}}(\boldsymbol{\mu \mathbf { g }} / \mathbf{m l})$ & $\mathbf{C C}_{\mathbf{5 0}}(\boldsymbol{\mu g} / \mathbf{m l})$ & $\mathbf{S I}$ \\
\hline O-methyloktadrenolon & $10.9 \pm 1.2$ & $63 \pm 2.3$ & 5.8 \\
Alloevodionol & $41.1 \pm 3.1$ & $>1000$ & $>24.3$ \\
Isopimpinellin & $>50$ & $>1000$ & $>20$ \\
Alloxanthoxyletin & $21.72 \pm 2.2$ & $93 \pm 3.0$ & 4.3 \\
Methylevodionol & $>50$ & $310 \pm 2.5$ & $>6.2$ \\
N-methylflindersine & $3.8 \pm 2.7$ & $97 \pm 3.3$ & 25.5 \\
\hline
\end{tabular}

Data represent mean \pm SD of triplicate experiments respectively. While, alloevodionol possess a moderate inhibition and the two remaining compounds, isopimpinellin, and methylevodionol did not show any inhibitive effect on HCV infection. The cellular viability assay demonstrated that all compounds had a negligible cytotoxicity effect with a $\mathrm{CC}_{50}>90 \mu \mathrm{g} / \mathrm{ml}$, except for O-methyloktadrenolon that had a $\mathrm{CC}_{50}$ of $63 \pm$ $2.3 \mu \mathrm{g} / \mathrm{ml}$ (Table 1 ).

Due to their efficacy, N-methylflindersine and Omethyloktadrenolon were tested on the different stages of HCV life cycle, in the entry step and post-entry steps. They were found to inhibit HCV in the post-entry step of HCV life cycle (Table 2). Western blot analysis was used to determine the mechanism by which this inhibition could occur and a reduction in the level of NS3 protease inhibitor was found. These results indicate that the compounds may interfere with the virus replication (Fig. 2).

\section{Discussion}

The six isolated compounds, O-methyloktadrenolon, alloevodionol, isopimpinellin, alloxanthoxyletin, methylevodionol, and $\mathrm{N}$-methylflindersine were previously isolated from the other plants [27-31]. Omethyloktadrenolon, alloevodionol and methylevodionol have been isolated from Melicope ptelefolia leaves along with 15 other benzopyran compounds [30]. Isopimpinellin has been isolated from Adiscanthus fusciflorus (Rutaceae) and reported to possess an inhibitory activity against the enzyme adenine phosphoribosyltransferase (APRT) from Leishmania spp. [32]. This genus contains the causative agents of leishmaniasis. Isopimpinellin was also indicated to have chemo-preventive effects when administered orally after skin tumour initiation by 7,12-dimethylben$z[\alpha]$ anthracene (DMBA) [33]. While, alloxanthoxyletin was previously isolated from Pilocarpus goudotianus (Rutaceae) [24]. An oil derived from the flower of Melicope lunu-akenda was found to contain ecodione (38.9\%), (E)- $\beta$-ocimene (12.4\%), isolycodolin (11.7\%) and alloevadionol (10.6\%) as major constituents. This oil exhibited antibacterial activity against Gram negative and Gram positive bacteria, in particular against Salmonella typhi and Klebsiella pneumonia, which are both human pathogens [34]. A quinolinone alkaloid, $\mathrm{N}$-methylflindersine was previously isolated from stem bark of Micromelum falcatum and showed strong toxicity towards brine shrimp larvae with a $\mathrm{LD}_{50}$ value of $1.39 \mu \mathrm{g} / \mathrm{ml}$ [27]. It was also isolated from Zanthoxylum integrifoliolum, another species belonging to the Rutaceae family. N-methylflindersine has been found to inhibit $\mathrm{N}$-formylmethionylleucylphenylalanineinduced superoxide production with an $\mathrm{IC}_{50}<12 \mu \mathrm{M}$ [28]. N-methylflindersine and methylevodionol have 
Table 2 Mode of action of compounds isolated from M. latifolia fruit extract

\begin{tabular}{|c|c|c|c|c|c|}
\hline \multirow[t]{2}{*}{ Sample } & \multirow{2}{*}{$\begin{array}{l}\text { Conc. } \\
\mu \mathrm{g} / \\
\mathrm{ml}\end{array}$} & \multicolumn{3}{|l|}{ \% Inhibition } & \multirow[t]{2}{*}{ Mode of action } \\
\hline & & $\begin{array}{l}\text { During+Post } \\
\text { inoculation }\end{array}$ & $\begin{array}{l}\text { During } \\
\text { inoculation }\end{array}$ & $\begin{array}{l}\text { Post } \\
\text { inoculation }\end{array}$ & \\
\hline $\mathrm{N}$-methylflindersine & 25 & $83 \pm 0.8$ & $7.7 \pm 1.8$ & $84.1 \pm 2.9$ & Post-entry inhibition \\
\hline O-methyloktadrenolon & 25 & $98.4 \pm 0.4$ & $9.1 \pm 8.5$ & $98 \pm 0.9$ & Post-entry inhibition \\
\hline
\end{tabular}

Data represent mean \pm SD of triplicate experiments

previously been isolated from the leaves of Melicope denhamii. In the same study, they showed moderate activity against murine leukemia P-388 cells with an $\mathrm{IC}_{50}$ value of $21.06 \mu \mathrm{g} / \mathrm{ml}$ and $11.98 \mu \mathrm{g} / \mathrm{ml}$ respectively [31]. In this study, anti-HCV activities of these compounds were evaluated and it was found that $\mathrm{N}$ methylflindersine was revealed the strongest $\mathrm{HCV}$ inhibition activity with $\mathrm{IC}_{50}$ value of $3.8 \pm 2.7 \mu \mathrm{g} / \mathrm{ml}$, followed by $\mathrm{O}$-methyloktadrenolon with an $\mathrm{IC}_{50}$ value of $10.9 \pm 1.2 \mu \mathrm{g} / \mathrm{ml}$. Alloevodionol and alloxanthoxyletin demonstrated a moderate activity with $\mathrm{IC}_{50}$ values of $41.1 \pm 3.1$ and $21.72 \pm 2.2 \mu \mathrm{g} / \mathrm{ml}$, respectively. On the other hand, methylevodionol and isopimpinellin, did not reveal anti-HCV activities at the highest concentration examined, $50 \mu \mathrm{g} / \mathrm{ml}$ (Table 1). Benzopyran compounds can form a benzoxazole moiety that can inhibit HCV by conjugation with a methylene thio (-SCH2-) linker that used to connect a heterobicycle with various aromatic rings by synthetically to form hybrid compounds for antiviral bioassays. The mode of action of the compound was found to be through inhibition in the post entry step by a reduction of HCV NS3 protein levels in dose dependent manner (Table 2; Fig. 2). N-methylflindersine is an alkaloid compound with the basic structure of quinoline. These quinolones compounds were known as antimicrobial, anticancer and antiallergic agents. Quinolones were reported to act as inhibitors of $\mathrm{HCV}$ NS5B RNA polymerase by binding to the allosteric site II (non-nucleoside inhibitor-site 2) of this protein [35-37]. Quinolone compounds consist of heterobicyclic aromatic compounds that may play an important role in anti-HCV activities.

\section{Conclusion}

The alkaloid compound, N-methylflindersine which was isolated from the M. latifolia fruit mediated a strong anti-HCV activity through post-entry inhibition and HCV NS3 protein reduction. This result suggests that $M$. latifolia is a potential candidate for developing an anti-HCV agent.

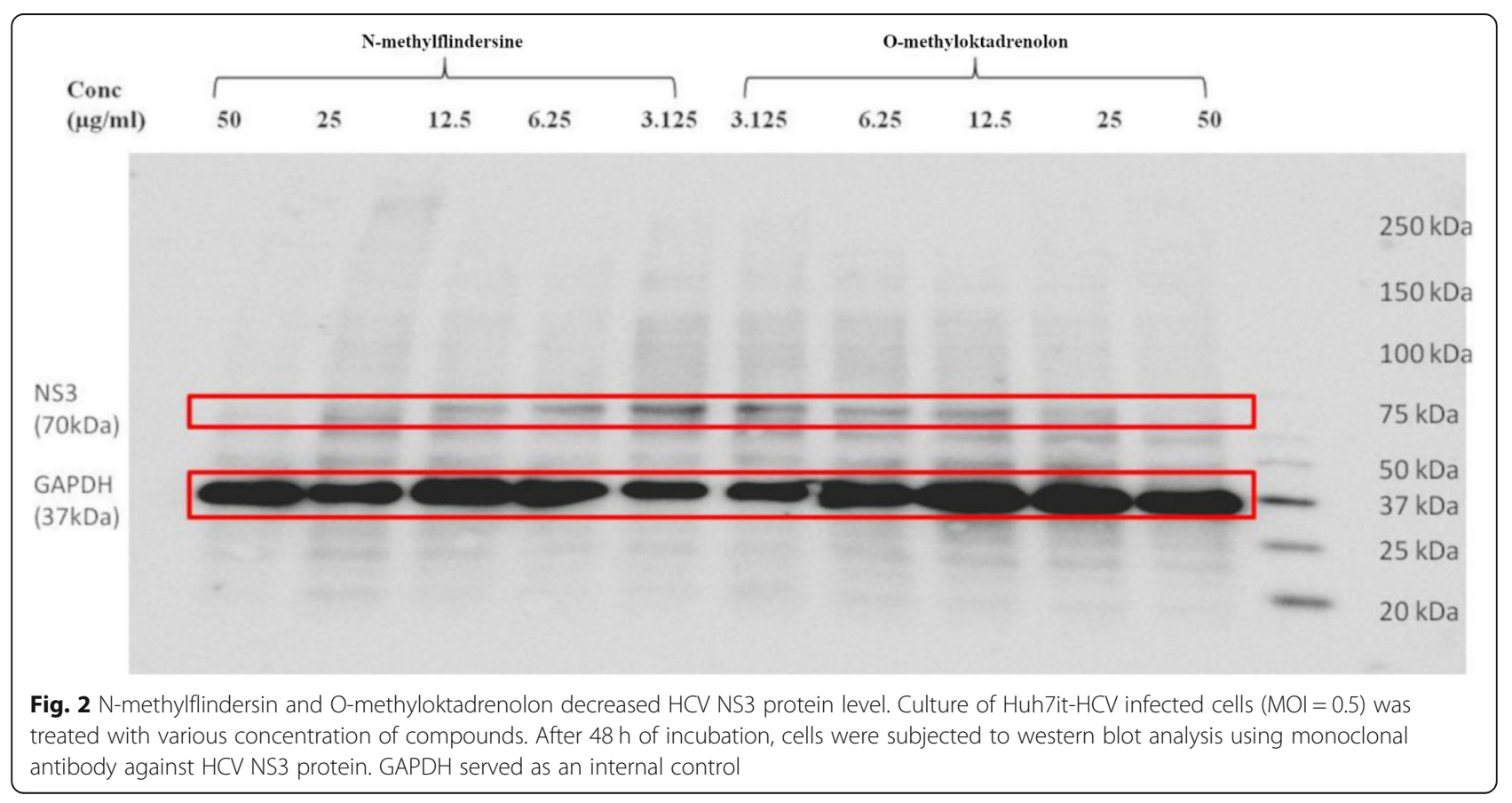




\section{Abbreviations}

BSA: Bovine Serum Albumin; BCA: Bichincronic Acid; $C_{50}$ : Cytotoxic Concentration 50\%; DAAs: Direct Acting Anti-Virals; DAB: 3,3'diaminobenzidine; DMEM: Dulbeco's Modiffied Eagle Medium; DMSO: Dimethyl sulfoxide; FBS: Fetal Bovine Serum; GAPDH: Glyceraldehyde3-phosphate dehydrogenase; HCV: Hepatitis C Virus; IC 50 : Inhibition Concentration 50\%; IR: Infrared spectrophotometry; MOl: Multiple of Infection; NEAA: Non-Essential Amino Acids; NMR: Nuclear Magnetic Resonance; PBS: Phosphate Buffer Saline; SVR: Sustain virology respond; UV: Ultra violet; VLC: Vacuum Liquid Chromatography

\section{Acknowledgements}

We thank to Takaji Wakita (National Institute for Infectious Diseases, Japan) and Dr.Yohko Shimizu (Kobe University) for providing JFH1 plasmid and Huh7it-1 cells.

\section{Authors' contributions}

Conceived and designed the experiment: AW, MT, AAP, RS, LT, HA and TSW. Analyzed the data: MA, AFH and TSW. Contributed reagents/materials/ analysis tools: AW, CAU, HH and TSW. Wrote the paper: AW, AAP and TSW. AW, CAU, HH and TSW contributed to the final version of the manuscript. All authors read and approved the final manuscript.

\section{Funding}

This research was granted by Universitas Airlangga through RISET MANDAT with grant number 398/UN3.14/LT/2019 and the funders had no role in the study design and analysis.

\section{Availability of data and materials}

The all data used to support the findings of this study are available from the corresponding or the first authors upon request.

\section{Ethics approval and consent to participate}

Not applicable.

\section{Consent for publication}

Not applicable.

\section{Competing interests}

The authors declare that they have no conflict of interest.

\section{Author details}

'Department of Pharmacognosy and Phytochemistry, Faculty of Pharmacy, Universitas Airlangga, Jl. Mulyorejo, Surabaya 60115, Indonesia. ${ }^{2}$ Institute of Tropical Disease, Universitas Airlangga, Jl. Mulyorejo, Surabaya 60115, Indonesia. ${ }^{3}$ Department of Chemistry, Faculty of Science and Technology, Universitas Airlangga, J. Mulyorejo, Surabaya 60115, Indonesia. ${ }^{4}$ Department of Public Health, Kobe University Graduate School of Health Sciences, 7-10-2, Tomogaoka, Suma-ku, Kobe 654-0142, Japan. ${ }^{5}$ Faculty of Clinical Nutrition and Dietetics, Konan Women's University, 6-2-23 Morikita-machi, Higashinada-ku, Kobe 658-0001, Japan.

\section{Received: 2 July 2020 Accepted: 4 January 2021}

\section{Published online: 12 January 2021}

\section{References}

1. Zingaretti C, De Francesco R, Abrignani S. Why is it so difficult to develop a hepatitis C virus preventive vaccine? Clin Microbiol Infect. 2014;20(Suppl 5): 103-9.

2. Blach S, Zeuzem S, Manns M, Altraif I, Duberg A-S, Muljono DH, et al. Global prevalence and genotype distribution of hepatitis $C$ virus infection in 2015: a modelling study. Lancet Gastroenterol Hepatol. 2017;2(3):161-76.

3. Manns MP, Foster GR, Rockstroh JK, Zeuzem S, Zoulim F, Houghton M. The way forward in HCV treatment--finding the right path. Nat Rev Drug Discov. 2007;6(12):991-1000

4. Swan D, Long J, Carr O, Flanagan J, Irish H, Keating S, et al. Barriers to and facilitators of hepatitis $C$ testing, management, and treatment among current and former injecting drug users: a qualitative exploration. AIDS Patient Care STDs. 2010;24(12):753-62.

5. Pawlotsky JM, Feld JJ, Zeuzem S, Hoofnagle JH. From non-A, non-B hepatitis to hepatitis C virus cure. J Hepatol. 2015;62(1 Suppl):S87-99.
6. Pawlotsky JMNF, Aghemo A, Berenguer M, Dalgard O, Dusheiko G, Marra F, Puoti $\mathrm{M}$, Wedemeyer $\mathrm{H}$. EASL recommendations on treatment of hepatitis $\mathrm{C}$ 2018. J Hepatol. 2018;69(2):461-511.

7. Calland N, Sahuc M-E, Belouzard S, Pène V, Bonnafous P, Mesalam AA, et al. Polyphenols inhibit hepatitis $C$ virus entry by a new mechanism of action. J Virol. 2015:89(19):10053-63.

8. Jardim ACG, Igloi Z, Shimizu JF, Santos VAFFM, Felippe LG, Mazzeu BF, et al. Natural compounds isolated from Brazilian plants are potent inhibitors of hepatitis C virus replication in vitro. Antivir Res. 2015;115:39-47.

9. Wahyuni TS, Utsubo CA, Hotta H. Promising anti-hepatitis $C$ virus compounds from natural resources. Nat Prod Commun. 2016;11(8):1193200.

10. Wahyuni TS, Tumewu L, Permanasari AA, Apriani E, Adianti M, Rahman A, et al. Antiviral activities of Indonesian medicinal plants in the East Java region against hepatitis C virus. Virol J. 2013;10:259.

11. Wahyuni TS, Widyawaruyanti A, Lusida MI, Fuad A, Soetjipto, Fuchino H, et al. Inhibition of hepatitis C virus replication by chalepin and pseudane IX isolated from Ruta angustifolia leaves. Fitoterapia. 2014;99:276-83.

12. Zeisel MB, Crouchet E, Baumert TF, Schuster C. Host-targeting agents to prevent and cure hepatitis C virus infection. Viruses. 2015;7(11):5659-85.

13. Saw LG, Chung RCK. The flora of Malaysia projects. Rodriguésia. 2015;66: 947-60.

14. Nguyen $\mathrm{NH}, \mathrm{Ha}$ TK, Choi S, Eum S, Lee $\mathrm{CH}$, Bach TT, et al. Chemical constituents from Melicope pteleifolia leaves. Phytochemistry. 2016;130:291300.

15. Dwi S, Adita Ayu P, Myrna A, Lidya T, Tutik Sri W, Mulyadi T, et al. The alkaloid fraction from melicope latifolia leaves inhibits hepatitis $C$ virus. Pharmacognosy J. 2020;12(3):535-40.

16. Cao M, Zhang Y, Peng Z-G, Jiang J, Gao Y, Hao X. Schoberine B, an alkaloid with an unprecedented straight $C 5$ side chain, and myriberine $B$ from Myrioneuron faberi. RSC Adv. 2016;6:10180-4.

17. McCormick JL, McKee TC, Cardellina JH 2nd, Boyd MR. HIV inhibitory natural products. 26. Quinoline alkaloids from Euodia roxburghiana. J Nat Prod. 1996:59(5):469-71.

18. Aoki C, Hartati S, Santi MR, Lydwina L, Firdaus R, Hanafi M, et al. Isolation and identification of substances with anti-hepatitis c virus activities from Kalanchoe pinnata. Int J Pharm Pharm Sci. 2014;6:211-5.

19. Kovac-Besović EE, Durić K. Thin layer chromatography-application in qualitative analysis on presence of coumarins and flavonoids in plant material. Bosnian J Basic Med Sci. 2003;3(3):19-26.

20. Hafid AF, Utsubo CA, Permanasari AA, Adianti M, Tumewu L, Widyawaruyanti $A$, et al. Antiviral activity of the dichloromethane extracts from Artocarpus heterophyllus leaves against hepatitis C virus. Asian Pac J Trop Biomed. 2017;7(7):633-9.

21. Apriyanto DR, Aoki C, Hartati S, Hanafi M, Kardono LB, Arsianti A, et al. Antihepatitis $C$ virus activity of a crude extract from Longan (Dimocarpus longan Lour.) leaves. Jpn J Infect Dis. 2016;69(3):213-20.

22. Kamperdick C, Van NH, Sung TV, Adam G. Benzopyrans from Melicope ptelefolia leaves. Phytochemistry. 1997;45(5):1049-56.

23. Siridechakorn I, Laphookhieo S. Chemical constituents from Feronia limonia roots. Chem Nat Compd. 2012;48(2):308-9.

24. Amaro-Luis JM, Massanet GM, Pando E, Rodriguez-Luis F, Zubia E. New Coumarins from Pilocarpus goudotianus. Planta Med. 1990;56(3):304-6.

25. Tanjung M, Saputri R, Wahjoedi RA, Tjahjandarie TSJM. 4-Methoxy-3-(3methylbut-2-en-1-yl)-7-[(3-methylbut-2-en-1-yl)oxy]quinolin-2(1H)-one from Melicope Moluccana T.G. Hartley. Molbank. 2017;2017:M939.

26. Kamperdick C, Van NH, Sung TV, Adam G. Bisquinolinone alkaloids from Melicope ptelefolia. Phytochemistry. 1999;50(1):177-81.

27. Luo XM, Qi SH, Yin H, Gao CH, Zhang S. Alkaloids from the stem bark of Micromelum falcatum. Chem Pharm Bull. 2009;57(6):600-2.

28. Chen JJ, Chen PH, Liao CH, Huang SY, Chen IS. New phenylpropenoids, bis(1phenylethyl) phenols, bisquinolinone alkaloid, and anti-inflammatory constituents from Zanthoxylum integrifoliolum. J Nat Prod. 2007;70(9):1444-8.

29. Jozwiak M, Struga M, Roszkowski P, Filipek A, Nowicka G, Olejarz W. Anticancer effects of alloxanthoxyletin and fatty acids esters - in vitro study on cancer HTB-140 and A549 cells. Biomed Pharmacother. 2019;110:618-30.

30. Kamperdick C, Van HN, Sung VT, Adam G. Benzopyrans from Melicope ptelefolia leaves. Phytochemistry. 1997;45(5):7.

31. Saputri DS, Tanjung M, Tjahjandarie TS. Cytotoxic activity of quinolinone alkaloids and acylphloroglucinol from the leaves of Melicope denhamii 2018: IOP conference. 
32. Napolitano HB, Silva M, Ellena J, Rocha WC, Vieira PC, Thiemann OH, et al. Redetermination and comparative structural study of isopimpinellin: a new inhibitor against the Leishmania APRT enzyme. Acta Crystallogr Sect E. 2003; 59(10):01506-08

33. Kleiner HE, Vulimiri SV, Starost MF, Reed MJ, DiGiovanni J. Oral administration of the citrus coumarin, isopimpinellin, blocks DNA adduct formation and skin tumor initiation by 7,12-dimethylbenz[a]anthracene in SENCAR mice. Carcinogenesis. 2002;23(10):1667-75.

34. Sabulal B, George V, Shiburaj S. Volatile constituents and antibacterial activity of the flower oil of Evodia lunu-ankenda (Gaertn) Merr. J Essent Oil Res. 2006;18(4):462-4.

35. Kumar DV, Rai R, Brameld KA, Somoza JR, Rajagopalan R, Janc JW, et al. Quinolones as HCV NS5B polymerase inhibitors. Bioorg Med Chem Lett. 2011;21(1):82-7.

36. Kumar DV, Rai R, Brameld KA, Riggs J, Somoza JR, Rajagopalan R, et al. 3Heterocyclyl quinolone inhibitors of the HCV NS5B polymerase. Bioorg Med Chem Lett. 2012;22(1):300-4.

37. Manvar D, Mishra M, Kumar S, Pandey VN. Identification and evaluation of anti hepatitis C virus phytochemicals from Eclipta alba. J Ethnopharmacol. 2012;144(3):545-54.

\section{Publisher's Note}

Springer Nature remains neutral with regard to jurisdictional claims in published maps and institutional affiliations.

Ready to submit your research? Choose BMC and benefit from:

- fast, convenient online submission

- thorough peer review by experienced researchers in your field

- rapid publication on acceptance

- support for research data, including large and complex data types

- gold Open Access which fosters wider collaboration and increased citations

- maximum visibility for your research: over $100 \mathrm{M}$ website views per year

At BMC, research is always in progress.

Learn more biomedcentral.com/submissions 